\title{
S5 - Módulo sanitario familiar para emergencias de rápida instalación (Mosafari)
}

\author{
Rubén R. Pérez \\ Escuela de Formación de Profesores de Enseñanza Media (EFPEM), Universidad de San Carlos de Guatemala
}

*Autor al que se dirige la correspondencia: rrperezoliva1@gmail.com

\section{Resumen}

Se propone un módulo sanitario familiar para emergencias de instalación rápida (Mosafari), cuyo establecimiento

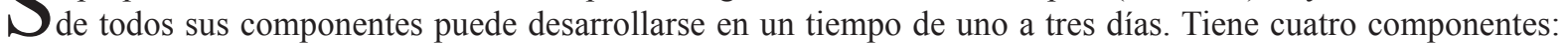
Primero el Sistema de abastecimiento de agua segura para consumo humano; que incluye captación de agua de lluvia, almacenamiento y desinfección del agua para consumo humano a nivel familiar (5 personas), comunitario (25 familias); el sistema de desinfección incluye filtración con arena y desinfección con plata coloidal. El segundo, es un sistema de baño familiar que incluye taza con separación de heces y orina (con reducidor para ser utilizado por niños/niñas, lavamanos, ducha y utensilios de higiene. El tercero es un sistema de disposición y tratamiento de aguas grises, que incluye trampa de grasas y sistema de infiltración (zanja sanitaria). Adicionalmente se incluyen dos sistemas, uno que consta de pila que se alimenta con captación de agua de lluvia; y otro que consta de un modelo de letrina abonera seca familiar (LASF). El área que utiliza el Mosafari no es mayor de $40 \mathrm{~m}^{2}$. Los costos de compra de insumos y materiales, instalación, operación y mantenimiento son bastante bajos y el tiempo de utilización del Mosafari no debe pasar de un año; aunque el tiempo puede ampliarse previa evaluación de sus componentes.

Palabras claves: Gestión de riesgo, tratamiento, desinfección, salud, tecnología apropiada

\begin{abstract}
$I^{\prime}$

$\mathrm{n}$ cases of emergencies and disasters we ready or not, the immediate response actions to the affected population, including measures such as providing water for human consumption; as well as the prevention of pollution from human faeces, solid waste and wastewater, to ensure environmental health of the affected population. The family health emergency module for quick installation (Mosafari) described and proposed was built next to the building occupied by the Regional School of Sanitary Engineering and Water Resources (ERIS), with financial resources of PAHO/WHO, developed this pilot project as an model educational, which serve as an example of how economically and appropriate technology, can give an answer in the short time (one to three days), compliance processes efficiently and effectively, ensuring that all its components be useful to address the emergency and the period in which it ceases to be.
\end{abstract}

Keywords: Risk management, treatment, disinfection, health, appropriate technology 